\title{
ANALISIS PENGGUNAAN BIKAGO DALAM ANIME KYOTO TERAMACHI SANJOU NO HOLMES
}

\author{
K. Bahiyah ${ }^{1}$, K.E.K. Adnyani ${ }^{2}$, N.N. Suartini ${ }^{3}$ \\ Jurusan Bahasa Asing, Universitas Pendidikan Ganesha, Singaraja \\ e-mail: khoridatul.bahiyah@undiksha.ac.id krishna.adnyani@undiksha.ac.id nnsuartini@undiksha.ac.id
}

\begin{abstract}
Abstrak
Penelitian ini bertujuan untuk mendeskripsikan penggunaan jenis dan fungsi bikago dalam anime Kyoto Teramachi Sanjou no Holmes. Pendekatan yang dilakukan adalah pendekatan kualitatif dengan metode pengumpulan data yakni metode simak dan catat. Kemudian untuk menganalisis jenis bikago menggunakan teori Hori (2010) dan teori fungsi bikago oleh Hinata (2000). Untuk menganalisis situasi tuturan menggunakan teori pragmatik yakni faktor-faktor tindak komunikatif oleh Noss dan Lamzon (1986). Hasil dari penelitian ini menunjukkan bahwa terdapat 18 data dan penggunaan 3 jenis bikago, yaitu o-wago, go-kango, dan o-kango. Dalam hasil penelitian ini juga ditemukan bahwa Bikago sering digunakan bagi orang yang memiliki pendidikan yang tinggi untuk memberikan kesan yang baik kepada mitra tutur. Fungsi bikago yang digunakan dalam anime ini adalah menyatakan penghormatan, menyatakan perasaan formal, menyatakan jarak, menjaga martabat, menyatakan kasih sayang, dan menyatakan sindiran.
\end{abstract}

Kata kunci: Bikago, anime, fungsi bikago.

要旨

本研究の目的は、アニメ「京都寺町参上のホームス」に使用される美化語の形および機能を明ら かにする。研究では、記述的定性的が使うことである。データは、実用的のコミュニケーション行為の 要因のNoss とLamzon (1986) の理論によって分析した。研究の結果は18データとお和語、ご漢語、お漢 語の 4 例である。研究の結果も、美化語は高学歴の人々が良い印象を与えるためによく使用する。この アニメで使われている美化語の機能は敬意として、敬意を表すこと、正式な状況を宣言すること、距離 を置くこと、尊厳を維持すること、愛情を表すこと、皮肉を表現するため使用された。

キーワード : 美化語、アニメ、美化語の機能

\section{Pendahuluan}

Memperindah kata (bikago) merupakan salah satu bentuk rasa hormat penutur terhadap mitra tutur secara tidak langsung, tanpa merendahkan diri penutur dan meninggikan mitra tutur. Memperindah kata (bikago) digunakan oleh beberapa tokoh dalam media hiburan seperti anime. Anime merupakan media hiburan yang digunakan oleh pembelajar bahasa Jepang untuk meningkatkan pemahaman dan pengetahuan bahasa Jepang. Tetapi bikago jarang diajarkan secara mendetail. Sehingga terkadang pembelajar bahasa Jepang kesusahan dalam menentukan bikago dalam bahasa Jepang. Hal ini dikhawatirkan terdapat kesalahan penggunaan bikago oleh pembelajar bahasa Jepang.

Menurut Ide dan Yoshida (1991) bikago merupakan kata yang diperindah dan salah satu bagian dari keigo yang tidak digunakan untuk mengekspresikan sikap hormat penutur kepada mitra tutur atau orang yang dibicarakan. Bikago merupakan sebuah kata bahasa Jepang yang berawalan o- (お) dan go- (ご). Menurut Hori (2010) bentuk-bentuk bikago ada 4, yakni o-wago (kata bahasa Jepang asli), go-kango (kata bahasa Cina), o-kango (kata dengan cara baca Cina dan Hiragana), go-wago (kata yang dibaca bahasa Jepang). Tetapi selain bikago, adapun 
JPBJ, Vol. 7 No. 1, Februari 2021

ISSN: 2613-9618

beberapa keigo yang memiliki prefiks 0 - dan go-, seperti sonkeigo dan kenjougo. Makadari itu, perlu diketahui fungsi dari jenis bikago sendiri ditinjau dari situasi atau peristiwa tutur.

Penggunaan bikago lebih sering digunakan oleh wanita dikarenakan seorang wanita ingin menunjukkan kepribadian yang baik dan bertutur kata dengan lembut atau juga untuk menampilkan kelas sosial yang tinggi (Rinda, 2016). Penelitian yang dilakukan oleh Lutvita (2013) menyatakan bahwa wanita pada usia tua lebih banyak menggunakan bikago dari pada wanita dan laki-laki yang berusia muda. Tetapi pada anime Kyoto Teramachi Sanjou no Holmes khususnya pada bikago sering digunakan oleh laki-laki pada usia muda dari pada wanita yang berusia lebih tua.

Berdasarkan paparan tersebut, penelitian ini bertujuan untuk menganalisis penggunaan bikago lebih mendalam khususnya pada anime Kyoto Teramachi Sanjou no Holmes. Sehingga lebih memahami akan penggunaan bikago dalam jenis dan fungsi bikago yang ada dalam anime Kyoto Teramachi Sanjou no Holmes. Dengan meninjau latar belakang keluarga dan pekerjaan tokoh yang terdapat pada alur anime ini, dapat memahami jenis, bentuk, dan fungsi bikago pada situasi tertentu sehingga menghilangkan pemahaman yang keliru tentang bikago.

Adapun penelitian sejenis yang membahas sebagai bentuk akan pentingnya penelitian bikago yang pernah dilakukan oleh Adnyani (2017). Pada penelitian Adnyani, membahas mengenai faktor penggunaan bikago pada ibu-ibu Jepang di Bali. Tetapi pada penelitian ini membahas mengenai jenis dan fungsi bikago pada tokoh utama laki-laki berdasarkan penutur dan situasi tutur penggunaan bikago berpengaruh. Dengan latar belakang diatas, berikut merupakan rumusan masalah dalam peneilitian ini.

1. Apa saja jenis bikago dalam anime Kyoto Teramachi Sanjou no Holmes?

2. Bagaimanakah fungsi bikago dalam anime Kyoto Teramachi Sanjou no Holmes?

Sesuai dengan rumusan masalah diatas, penelitian ini bertujuan untuk mendeskripsikan jenis dan fungsi bikago dalam anime Kyoto Teramachi Sanjou no Holmes. Selain itu, penelitian ini juga bertujuan untuk memberikan wawasan yang lebih luas tentang penggunaan bikago melalui anime Kyoto Teramachi Sanjou no Holmes.

\section{Pragmatik}

Pragmatik membahas tentang makna suatu kalimat yang diucapkan oleh penutur yang sesuai dengan konteks dan situasi. Berhubungan dengan penggunaan bahasa dalam suatu konteks dan situasi penelitian ini akan menggunakan teori faktor-faktor tindak komunikatif oleh Noss dan Lamzon. Menurut Noss dan Lamzon (dalam Surastina. 2011:7) terdapat aspek yang perlu diperhatikan dalam penggunaan bahasa dalam berkomunikasi yakni penutur, mitra tutur, tujuan tuturan, konteks tuturan, media dalam tuturan dan peristiwa tutur. Namun dalam penelitian ini hanya menggunakan 4 faktor tindak komunikatif, yakni penutur dan mitra tutur, tujuan tuturan, konteks tuturan, dan peristiwa tutur.

1. Penutur dan mitra tutur

Penutur dan mitra tutur memiliki hubungan timbal balik dalam berkomunikasi. Penutur dan mitra tutur berkaitan dengan beberapa aspek seperti usia, latar belakang sosial, ekonomi, jenis kelamin, dan keakraban.

2. Tujuan tuturan

Dalam tiap tuturan memiliki tujuan atau maksud yang ingin disampaikan secara tidak langsung. Tujuan tuturan ini disampaikan karena terdapat suatu hal yang ingin didapat oleh penutur. Dalam tiap tuturan memiliki bentuk tuturan yang berbeda namun tujuan yang sama dan bentuk tuturan yang sama namun tujuan berbeda.

3. Konteks tuturan

Konteks tuturan bersangkutan dengan segala aspek setting sosial. Dalam pragmatik, konteks ini untuk mengetahui pengetahun yang dipahami oleh penutur dan mitra tutur. 
JPBJ, Vol. 7 No. 1, Februari 2021

ISSN: 2613-9618

\section{Peristiwa tutur}

Peristiwa tutur berkaitan dengan situasi atau kondisi dan keadaan yang sedang terjadinya tindak komunikasi oleh penutur dan mitra tutur. Seperti situasi formal ketika penutur dan mitra tutur sedang berkomunikasi dalam sebuah rapat.

\section{Bikago}

Menurut Takahashi (2016) bikago merupakan salah satu jenis keigo. Bikago adalah pengungkapan ekspresi untuk menyatakan kata benda secara halus. Perbedaan bikago dengan jenis keigo lainnya adalah kata yang memiliki prefix 0 - dan go-ditujukan untuk penutur (Takahashi. 2016:115). Apabila penggunaan o- dan go- ditujukan untuk mitra tutur atau orang yang dibicarakan maka hal itu disebut kenjougo. Sedangkan ciri-ciri dari bikago adalah prefiks o- dan go- yang bertujuan untuk menghaluskan sebuah kata yang digunakan oleh penutur. Menurut Ide dan Yoshida (dalam Tsujimura. 2002:470) dalam ciri leksikal, penggunaan bikago oleh masyarakat Jepang dikenal dengan sebuah santun bahasa yang sering digunakan oleh wanita. Hal ini guna menunjukkan martabat diri seorang wanita. Menurut Ide dan Yoshida (dalam Tsujimura. 2002:470) penutur yang menggunakan bikago memiliki maksud untuk menampilkan sikap baik dan berkelas. Bikago juga digunakan oleh penutur untuk menunjukkan kelas sosial yang tinggi. Dengan menunjukkan kelas sosial yang tinggi maka penutur akan mendapatkan kesan baik dan berpendidikan bagi mitra tutur. Menurut Nakao (dalam Sudjianto dan Dahidi. 2014: 189) faktor yang mempengaruhi penggunaan bikago yang merupakan salah satu jenis keigo adalah usia, status, jenis kelamin, keakraban, gaya bahasa, pribadi atau umum, dan pendidikan.

Penggunaan prefiks 0 - pada umumnya berada pada kata benda yang dibaca huruf Jepang, yakni wago. Sedangkan prefiks go-digunakan kata benda yang dibaca huruf Cina, yakni kango. Tetapi menurut Hori (2010) terdapat 4 bentuk bikago, yakni, o-wago, go-kango, o-kango, dan go-wago.

1. O-wago

Wago adalah kata-kata asli bahasa Jepang yang memiliki ciri-ciri dengan dibaca kunyomi yang ditambahkan o-pada awalan kata. Seperti お二人 (o-futarı), お昼 (o-hiru), お 酒 (o-sake).

2. Go-kango

Kango adalah kata-kata yang diambil dari Cina lalu dijadikan bahasa Jepang sebagai bahasanya sendiri dan terdapat awalan go-pada awalan kango. Seperti ご自分 (go-jibun) dan ご用件 (go-youken).

3. O-kango

Go-kango dengan o-kango memiliki persamaan yakni dibaca onyomi (Cina) dan juga penulisan dengan menggunakan huruf hiragana. Namun pada o-kango terdapat 9 data yang memiliki aturan yang berbeda seperti お勉強 (o-benkyou) dan お料理 (o-ryouri).

4. Go-wago

Go-wago adalah kata yang berasal dari Jepang namun dalam bahasa modern ditemukannya beberapa kata yang menggunakan prefiks go- dalam kata bahasa Jepang. Kosakata Go-wago terdapat pada waktu dan situasi Seperti ごゆっくり (go-yukkuri) dan ご もっとも (go-mottomo). Kosakata yang memiliki prefiks go dan menunjukkan pada keterangan waktu dan situasi digolongkan dalam kamus bahasa modern di Jepang.

Dalam tiap tuturan memiliki fungsi yang menyatakan suatu hal secara tidak langsung. Bikago juga memiliki fungsi yang sama dalam pemilihan kata kepada mitra tutur. Adapun beberapa fungsi bikago yang merupakan salah satu jenis keigo dari segi penutur menurut Hinata (dalam Sudjianto dan Dahidi, 2014: 195). 
JPBJ, Vol. 7 No. 1, Februari 2021

ISSN: 2613-9618

a. Menyatakan Penghormatan

Keigo merupakan salah satu cara untuk menyatakan rasa sopan dan hormat pada mitra tutur. Bahasa yang menyatakan penghormatan digunakan oleh penutur untuk bersosialisasi dengan mitra tutur yang memiliki status sosial yang lebih tinggi dari penutur. Seperti tuturan karyawan kepada atasannya.

b. Menyatakan perasaan formal

Keigo bisa digunakan untuk menyatakan perasaan formal. Hal ini bersangkutan dengan situasi resmi. Keigo digunakan dengan gaya bahasa yang formal dan kaku seperti halnya bahasa hormat sebagai etika sosial.

c. Menyatakan jarak

Pada umumnya, seseorang akan menggunakan keigo ketika bertemu dengan orang yang baru ditemui. Hal ini dilakukan untuk menjaga perasaan mitra tutur. Namun keigo sebaiknya digunakan sewajarnya karena penggunaan keigo yang berlebihan akan menjadi kasar dan kurang sopan.

d. Menjaga Martabat

Untuk menjaga martabat seseorang, pada umumnya penutur menggunakan keigo. Hal ini dilakukan untuk menunjukkan martabat kepada mitra tutur, baik menunjukkan rasa hormat maupun tidak. Karena dengan menggunakan keigo penutur dapat menyatakan pendidikan penutur dan martabat penutur.

e. Menyatakan Kasih Sayang

Keigo juga dapat menyatakan rasa kasih sayang penutur kepada orang sekitarnya. Hal ini menunjukkan bahwa penutur memiliki sikap yang baik. Keigo yang menyatakan kasih sayang juga terkadang digunakan oleh orang tua kepada anak atau guru kepada murid. Kasih sayang ini tidak hanya diungkapkan hanya untuk manusia namun juga bisa dengan benda, seperti benda yang di sukai.

f. Menyatakan sindiran atau celaan

Keigo dapat digunakan untuk menyindir dengan halus. Kebalikan dari bentuk kesopanan, keefektifan keigo dapat dibalik menjadi sindiran atau celaan.

\section{Metode}

Metode pengumpulan data dalam penelitian ini yakni dengan metode simak dan metode catat. Dalam mengumpulkan dan menemukan data penelitian dengan menyimak dan mencatat kata bikago dalam anime Kyoto Teramachi Sanjou no Holmes. Mencatat data yang relevan dengan rumusan masalah. Setelah mendapat data yang diinginkan, data dimasukkan kedalam kartu data untuk mempermudah menganalisis jenis dan fungsi bikago. Data yang telah dikumpulkan dijabarkan dalam bentuk paragraf untuk memperjelas hasil penelitian.

Dalam penelitian ini, data diolah dengan menggunakan metode deskriptif. Data yang dianalisis adalah bikago dalam anime Kyoto Teramachi sanjou no Holmes. Adapun langkahlangkah penelitian, yakni sebagai berikut:

1. Melihat dan menyimak sumber data dalam anime Kyoto Teramachi Sanjou no Holmes.

2. Mengumpulkan data kata yang mengandung bikago.

3. Mengidentifikasi jenis dan fungsi bikago dalam anime Kyoto Teramachi Sanjou no Holmes

4. Menjabarkan bikago yang terdapat dalam anime Kyoto Teramachi Sanjou no Holmes dalam bentuk paragraf dan membuat kesimpulan.

\section{Hasil dan Pembahasan}

Berdasarkan hasil penelitian penggunaan bikago dalam anime Kyoto Termachi Sanjou no Holmes ditemukan 3 jenis bikago yakni o-wago, go-kango, dan o-kango. Jenis o-wago terdapat 10 data. Jenis go-kango terdapat 2 data. Sedangkan jenis o-kango terdapat 6 data. Dalam hasil penelitian fungsi bikago dalam anime Kyoto Teramachi Sanjou no Holmes ditemukan 6 fungsi 
JPBJ, Vol. 7 No. 1, Februari 2021

ISSN: 2613-9618

bikago, yakni menyatakan hormat, menjaga martabat, menyatakan kasih sayang, menyatakan jarak, menyatakan sindiran atau celaan, dan menyatakan formal.

\section{Data 1}

Kiyotaka:どうかありましたか。

(douka arimashitaka?)

Ada apa?

Aoi:いーいいえ、ちょっと初めてお店に来た時のこと思い出してまして。

( $i$ iie, chotto hajimete o-mise ni kita toki no koto omoidashite mashite)

Ti tidak. Sedikit teringat ketika saya baru datang ke toko ini.

Kiyotaka:あれから 2 週間ほどですか。早いものですね。

(arekara 2 shuukan hodo desuka. Hayai mono desune.)

Sudah sekitar 2 minggu-an ya. Cepet ya.

Aoi: ええ。あのうお掃除は終わりました。

(Ee. Anou, o-souji wa owarimashita.)

lya. Itu, saya sudah selesai bersih-bersih.

Situasi:

Aoi membersihkan toko Kura sambil melamun dan disadarkan oleh Kiyotaka. Lalu Aoi mengkonfirmasi kepada Kiyotaka bahwa Aoi sudah selesai membersihkan tokonya.

Analisis:

Data 1 merupakan tuturan Aoi yang ditujukan kepada Kiyotaka. Tuturan data 1 merupakan penggunaan jenis bikago yakni $O$-kango dalam bentuk $O$-souji yang memiliki arti pembersihan.

Berdasarkan situasi tuturan, Kiyotaka merupakan atasan Aoi di toko Kura. Setelah membersihkan toko, Aoi mengkonfimasi pekerjaan yang telah selesai Aoi kerjakan kepada Kiyotaka. Aoi bermaksud ingin menanyakan pekerjaan apa lagi yang perlu dilakukan Aoi sebagai pegawai di toko Kura. Dalam situasi bekerja, pegawai menggunakan bahasa sopan kepada atasannya. Sehingga Aoi pun menggunakan bahasa sopan kepada Kiyotaka. Aoi menggunakan bikago bertujuan untuk mengkonfirmasi kepada Kiyotaka mengenai apa yang telah dikerjakan dan menanyakan apa yang harus dilakukan selanjutnya. Aoi menggunakan bikago untuk menciptakan kesan baik kepada Kiyotaka yang sebagai atasan dalam hal pekerjaan. Hal ini berhubungan dengan fungsi bikago menurut Hinata (dalam Sudjianto dan Dahidi. 2014: 195) yakni kosakata yang digunakan oleh Aoi menyatakan penghormatan kepada Kiyotaka yang merupakan cucu pemilik toko Kura atau atasan ditempat Aoi bekerja.

\section{Data 2}

Kiyotaka: そうだ、青いさん。今からめいのカフェ様子を見に行くんですよ。ご一緒によ゙うでし ようか。

(Sou da, Aoi san. Ima kara mei no kafe yousu o mi ni ikun desuyo. Go-isshoni dou deshouka.) Mulai sekarang saya akan melihat keadaan kafe. Apa kamu bersedia menemaniku?

Situasi:

Kiyotaka diundang oleh ibu Aoi untuk datang ke rumah Aoi. Hal ini karena ibu Aoi ingin berterimakasih pada Kiyotaka yang telah mengajarkan berbagai macam mata pelajaran kepada Aoi sehingga nilai-nilai Aoi menjadi tinggi. Di rumah Aoi, Kiyotaka duduk sembari minum teh bersama Aoi di kamar Aoi. Kemudian Kiyotaka menawarkan untuk pergi ke kafe bersama.

Analisis:

Data 2 merupakan tuturan Kiyotaka kepada Aoi. Kiyotaka menggunakan salah satu jenis bikago yakni go-kango, kosakata yang berasal Cina yang terdapat prefiks go- (Hori. 2010). Bentuk dari go-kango adalah go-isshoni yang memiliki arti bersama.

Berdasarkan situasi tuturan Kiyotaka ingin mengajak Aoi untuk pergi bersama-sama untuk melihat kafe yang akan menjadi tempat bekerja sementara bagi Kiyotaka. Ajakan Kiyotaka 
JPBJ, Vol. 7 No. 1, Februari 2021

ISSN: 2613-9618

dikarenakan Aoi juga ingin melihat kafe milik salah satu pelanggan toko Kura yang sudah akrab dengan Aoi. Menurut Kiyotaka, Aoi merupakan seorang karyawan, murid, dan teman bagi Kiyotaka. Kiyotaka senang bekerja bersama Aoi, membantu Aoi belajar, dan juga merasa akrab karena saling bercerita mengenai diri masing-masing. Oleh karena itu fungsi bikago yang digunakan oleh Kiyotaka adalah untuk menyatakan kasih sayang kepada Aoi. Hal ini cocok dengan salah satu fungsi bikago menurut Hinata (dalam Sudjianto dan Dahidi. 2014: 195) yakni menyatakan kasih sayang karena Kiyotaka menyayangi Aoi sebagai karyawan, murid, dan teman.

\section{Data 3}

Kiyotaka: 葵さん。葵さんが持ってくれたこのあかごの絵を見てください。 (Aoi-san. Aoi-san ga motte kureta kono akago no e o mite kudasai.)

Aoi, silahkan lihat lukisan bayi yang kamu bawa.

Aoi: 絵をですか。

(E o desuka?)

Lukisan?

Kiyotaka: 駿河には過ぎたるものが二つあり、富士のお山に腹の白隠。

(Suruga ni wa sugitaru mono ga futatsu ari fudo no o-yama hara no hakuon.)

Di Suruga ada 2 kelimpahan besar yakni gunung Fuji dan bidang berjubah putih

Situasi:

Aoi ingin menjual barang antik di toko kura. Kiyotaka secara singkat menjelaskan sejarah dan keaslian kedua barang antik yang dibawa oleh Aoi sebagai seorang pelanggan toko Kura pada umumnya.

Analisis:

Data 3 merupakan tuturan Kiyotaka kepada Aoi. Kiyotaka menggunakan salah satu jenis bikago yakni o-wago. Bentuk dari o-wago adalah o-yama yang memiliki arti gunung.

Berdasarkan situasi tuturan Aoi baru pertama kali bertemu dengan Kiyotaka dan ingin menjual barang antik di toko Kura. Kiyotaka menjelaskan lukisan tersebut yang akan dijual oleh Aoi. Kiyotaka menggunakan bikago bertujuan untuk menjelaskan sejarah kepada Aoi secara sopan tanpa menggurui. Dilihat dari situasi tuturan bermaksud memberikan kesan bahwa Kiyotaka menghargai barang antik yang dibawa oleh Aoi dan memberikan kesan bahwa Kiyotaka merupakan orang yang memiliki pengetahuan mengenai barang antik. Berdasarkan hal tersebut sesuai dengan teori Hinata (dalam Sudjianto dan Dahidi. 2014:195) fungsi bikago yang digunakan Kiyotaka adalah menyatakan perasaan formal kepada Aoi yang ingin dinilai keaslian barang antik yang dibawa oleh Aoi unutk dijual ke toko Kura.

\section{Data 4}

Kiyotaka: コーヒーを入れますよ。飲めますか。

(kōhīo iremasu yo. Nomemasuka?)

Aku bias membuat kopi. Apa kamu mau?

Aoi: お砂糖とミルクがあれば。

(O-satou to miruku ga areba.)

Mau kalau ada gula dan susu.

Kiyotaka:それではカフェオーレーを入れましょう。

(soredewa kafe ōrē o iremashou.)

Kalua begitu, ayo buat cafè au lait.

Situasi:

Aoi dan Kiyotaka pertama kali bertemu di toko Kura. Setelah Kiyotaka memperhatikan perilaku Aoi, Kiyotaka menghampiri Aoi dan menebak dengan benar dan frontal secara detail 
JPBJ, Vol. 7 No. 1, Februari 2021

ISSN: 2613-9618

tujuan Aoi datang ke toko Kura. Perkataan Kiyotaka tersebut membuat Aoi tidak nyaman untuk orang yang baru pertama kali bertemu. Menyadari ketidaknyamanan Aoi, Kiyotaka menawarkan minum teh sambil melanjutkan perbincangan mengenai barang antik yang ingin dijual Aoi. Karena Kiyotaka merupakan orang yang tidak dikenali Aoi dan tuturan Kiyotaka yang tidak nyaman kepada Aoi, tawaran Kiyotaka dijawab dengan sopan untuk menjaga jarak dengan Kiyotaka.

Analisis:

Data 4 merupakan tuturan Aoi kepada Kiyotaka. Aoi menggunakan salah satu jenis bikago yakni o-kango. Bentuk o-kango adalah o-satou yang memiliki arti gula.

Berdasarkan situasi tuturan, Aoi baru pertama kali bertemu dengan Kiyotaka. Sehingga Aoi menggunakan bikago bertujuan untuk bersikap formal dan sopan kepada kiyotaka yang sebagai orang yang baru ditemui Aoi. Dalam tuturan permintaan Aoi, Aoi menggunakan bikago untuk memberikan kesan sopan kepada Kiyotaka namun tetap menjaga jarak. Hal ini sesuai dengan teori Fungsi bikago menurut Hinata (dalam Sudjianto dan Dahidi. 2014:195) pada kosakata yang digunakan oleh Aoi adalah untuk menyatakan jarak kepada Kiyotaka yang baru saja ditemui ketika akan menjual barang antik yang Aoi bawa dari rumahnya ke toko Kura.

\section{Data 5}

Tamane: あおいさん、お店にはもうなれましたか。

(Aoi-san o-mise ni wa mou naremashitaka.)

Aoi, apa kamu sudah terbiasa dengan toko ini?

Aoi: はい、おかげさまで。

(hai, okage sama de.)

lya. Berkat anda saya sudah terbiasa.

Tamane: それは良かったです。

(Sore wa yokatta desu.)

Kalau begitu syukurlah.

Situasi:

Aoi sedang belajar barang antik kepada Kiyotaka lalu menyapa Tamane sebelum berpamitan untuk pergi keluar. Tamane menyapa Aoi dan menanyakan perasaan Aoi ketika bekerja di toko Kura sebagai bos yang mempedulikan pegawainya. Setelah Tamane berkomunikasi dengan Aoi, tamane memberitahukan kepada Kiyotaka dan Aoi bahwa Tamane akan pergi keluar untuk melakukan pekerjaan lainnya yakni mengenai novel.

Analisis:

Data 5 merupakan tuturan ayah Kiyotaka yang bernama Tamane kepada Aoi. Tamane menggunakan salah satu jenis bikago yakni o-wago, yakni kosakata berasal dari Jepang yang terdapat prefiks $O$ (Hori. 2010). Bentuk dari o-wago adalah o-mise yang memiliki arti toko.

Penggunaan tuturan bikago memiliki tujuan untuk menanyakan kenyamanan toko keluarga Kiyotaka kepada karyawannya. Berdasarkan situasi tuturan tamane yang merupakan ayah Kiyotaka dan pemilik toko Kura menanyakan kepada Aoi sebagai karyawan di toko Kura. Sebagai penilai barang antik tamane memiliki pengetahuan lebih daripada Aoi. Sehingga Tamane menggunakan bikago untuk menumbuhkan kesan wibawa namun masih tetap memiliki makna menghormati Aoi. Hal tersebut sesuai dengan Fungsi bikago menurut Hinata (dalam Sudjianto dan Dahidi. 2014:195) dimana kosakata yang digunakan oleh Tamane adalah untuk menjaga martabat Tamane sebagai pemilik toko kepada karyawannya.

\section{Data 6}

Aoi: 何か他に仕事はありませんか。

(Nanika hoka ni shigoto wa arimasenka?)

Apa pekerjaan lain yang perlu saya lakukan? 
JPBJ, Vol. 7 No. 1, Februari 2021

ISSN: 2613-9618

Kiyotaka: そうですね。特にありませんし、お勉強タイムに入りましょうか。(Soudesu ne. toku ni arimasenshi, o-benkyou taimu ni hairimashouka.)

Hmm. Tidak ada lagi sih. Bagaimana kalau waktunya kita untuk belajar?

Aoi: はい、ホームズさん。

(Hai, hōmuzu-san.)

Baik. Pak holmes.

Situasi:

Aoi sudah menyelesaikan pekerjaannya dan menanyakan apa yang yang perlu dilakukan oleh Aoi selanjutnya sebagai pegawai di toko Kura. Kiyotaka dengan senang menawarkan untuk belajar tentang barang antik kepada Aoi.

Analisis:

Data 6 merupakan bentuk tuturan Kiyotaka kepada Aoi. Kiyotaka menggunakan salah satu jenis bikago yakni o-kango, kosakata Cina yang terdapat prefiks o- (Hori. 2010). Bentuk dari okango adalah o-benkyou yang memiliki arti belajar.

Berdasarkan situasi tuturan Aoi sebagai karyawan baru di toko Kura tidak mengetahui tentang barang antik dan penasaran mengenai semua hal tentang barang antik. Kiyotaka yang sebagai penilai barang antik dengan senang hati mengajarkan Aoi semua hal tentang barang antik. Dari situasi tersebut penggunaan tuturan bikago oleh Kiyotaka bertujuan untuk menawarkan belajar kepada Aoi untuk belajar tentang barang antik yang disukai oleh Kiyotaka. Hal ini sesuai dengan teori Hinata (dalam Sudjianto dan Dahidi. 2014:195) tentang fungsi bikago yakni menyatakan kasih sayang. Hal ini ditunjukkan pada kosakata yang digunakan oleh Kiyotaka kepada barang antik yang akan diajarkan kepada Aoi. Kiyotaka belajar mengenai barang antik karena ketertarikan Kiyotaka kepada barang antik sangat tinggi sehingga Kiyotaka lebih suka dikenal sebagai penilai barang antik daripada detektif.

\section{Data 7}

Kakek Kiyotaka: 清貴、そんなとこで彼女とお楽しみか。

(Kiyotaka, sonna toko de kanojo to o-tanoshimi ka.)

Apa kamu sedang bersenang-senang dengan pacarmu?

Kiyotaka: オーナー。彼女は店を手伝ってくれてる葵真城さんですよ。電話でほうかくしたです よ。

(Ōnā. Kanojo wa mise o tetsudatte kureteru aoi mashiro-san desu yo. Denwa de houkakushita desu yo.

Pemilik toko. Ini Mashori Aoi yang membantu di toko. Aku sudah memberitahumu melalui telepon, kan?

Situasi:

kakek Kiyotaka singgah ke toko Kura sebentar untuk mengingatkan Kiyotaka mengenai pemalsuan barang antik yang semakin banyak diperjual belikan. Di toko Kura, kakek Kiyotaka melihat Kiyotaka berbicara dengan pegawai baru yang belum ditemui oleh kakek Kiyotaka yakni Aoi. Kakek Kiyotaka menggoda cucunya karena Kiyotaka terlihat senang berbicara dengan Aoi. Analisis:

Data 7 merupakan tuturan kakek Kiyotaka kepada Kiyotaka. Tuturan pada data 7 merupakan penggunaan jenis bikago yakni o-wago. Bentuk dari o-wago adalah o-tanoshimi yang memiliki arti kesenangan.

Penggunaan bikago yang digunakan oleh kakek Kiyotaka bertujuan untuk menggoda Kiyotaka yang sedang senang berbicara dengan Aoi. Kakek Kiyotaka merupakan mantan pemilik toko Kura dan seorang penilai barang antik. Sebagai penilai barang antik, kakek Kiyotaka memiliki pengetahuan mengenai semua hal yang berhubungan barang antik. Kiyotaka merupakan cucu satu-satunya dan juga mewarisi profesi penilai barang antik dengan senang hati. Berdasarkan hal tersebut kakek Kiyotaka sangat menyukai Kiyotaka. Hal ini sesuai dengan 
JPBJ, Vol. 7 No. 1, Februari 2021

ISSN: 2613-9618

teori fungsi bikago menurut Hinata (dalam Sudjianto dan Dahidi. 2014:195) yakni menyatakan kasih sayang. Kakek Kiyotaka menyatakan kasih sayang kepada cucunya yang sedang senang berbicara dengan karyawannya.

\section{Data 8}

Kiyotaka: というわけで、みやしたさんこれはお返ししますね。

(To iu wake de, miyashita-san kore wa o-kaeshishimasu ne.)

Kalau begitu, bu Miyashita aku rasa aku harus mengembalikan ini.

Ibu Miyashita: 本無理、お恥ずかしいこと。

(Hon muri, o-hazukashii koto.)

Maaf, sungguh ini hal memalukan.

Situasi:

Kiyotaka menemukan pelaku teror pada keluarga Miyashita. Dan pelaku teror tersebut merupakan kedua anak ibu Miyashita sendiri. Tujuannya untuk menggagalkan penobatan Saiodai pada Kaori, yang merupakan salah satu anak ibu Miyashita. Ibu Miyashita menunduk untuk meminta maaf kepada Kiyotaka karena perlakuan anak-anaknya yang telah merepotkan waktu Kiyotaka.

Analisis:

Pada tuturan data 8 digunakan jenis bikago yakni o-wago. Bentuk dari o-wago adalah 0 hazukashii yang memiliki arti malu.

Penggunaan bikago bertujuan untuk meminta maaf kepada Kiyotaka yang telah direpotkan oleh keluarga Miyashita. Keluarga Miyashita mengunjungi Kiyotaka untuk mencari tahu dalang dari teror yang terjadi 2 kali pada anaknya, Saori Miyashita. Ibu Miyashita sangat membanggakan anaknya yang merupakan Saio dai atau wanita yang dipilih sebagai peran utama dalam festival Aoi di Kyoto. Keluarga Miyashita mengira teror dikirim kepada Saori karena terdapat orang yang iri kepada Saori. Sehingga keluarga Miyashita memutuskan untuk menyelidiki kasus tersebut dan meminta pertolongan kepada Kiyotaka. Namun setelah Kiyotaka menyelidiki kasus tersebut, Kaori Miyashita dan Saori Miyashita adalah pelaku dari surat tersebut. Berdasarkan hal tersebut ibu Miyashita malu dan kecewa kepada kedua putrinya. Dilihat dari situasi tuturan terdapat fungsi bikago yang digunakan oleh ibu Miyashita adalah untuk menyindir kedua anaknya dan menyatakan kekecewaannya secara tidak langsung kepada kedua anaknya yang telah melakukan hal yang memalukan. Hal ini sesuai dengan teori fungsi bikago menurut Hinata (dalam Sudjianto dan Dahidi. 2014:195).

\section{Data 9}

Akihito: そうか。葵ちゃんのゆかたすがたを見られるなんて良いとききたいよ。 (Souka. Aoi-chan no yukata sugata o mirareru nante ii koto ni kikitai yo Syukurlah aku dapat melihat saat Aoi memakai yukata.

Kiyotaka: あきひとさん、お礼は済んだのですから、もうお帰りいただいても結構です。 (Akihito-san, o-rei wa sunda no desukara, mou okaeri itadaite mo kekkou desu.)

Karena rasa terima kasihmu sudah selesai, kamu sudah bisa pulang.

Situasi:

Kiyotaka, Akihito, dan beberapa pelanggan toko Kura sedang minum teh pemberian dari Akihito sebagai tanda terima kasih Akihito kepada Kiyotaka. Aoi datang dengan memakai yukata untuk pertama kalinya membuat Kiyotaka, Akihito dan beberapa pelanggan di toko Kura terkejut melihat Aoi. Akihito ingin mencoba menggoda dan merayu Aoi. Sehingga hal itu membuat Aoi tidak nyaman dan Kiyotaka pun langsung mendekati Aoi untuk melindungi Aoi dan menghentikan tindakan Akihito. 
JPBJ, Vol. 7 No. 1, Februari 2021

ISSN: 2613-9618

Analisis:

Data 9 merupakan tuturan Kiyotaka kepada Akihito. Tuturan data 9 merupakan penggunaan jenis bikago yakni o-kango. Bentuk dari o-kango adalah o-rei yang memilki arti terima kasih.

Berdasarkan situasi tuturan Akihito menggoda Aoi yang sedang menggunakan yukata ketika sedang bekerja. Dengan menggunakan bikago Kiyotaka menyatakan ketidaksukaan Kiyotaka terhadap tindakan Akihito yang merupakan salah satu pelanggan toko Kura. Sehingga Kiyotaka menggunaan bikago yang bertujuan untuk menghentikan candaan Akihito yang membuat Aoi tidak nyaman. Dilihat dari situasi ujaran terdapat salah satu teori fungsi bikago yang menyatakan sindiran atau celaan digunakan oleh Kiyotaka adalah untuk menyindir Akihito yang menggangu kenyamanan Aoi. Hal ini sesuai dengan teori fungsi bikago menurut Hinata (dalam Sudjianto dan Dahidi. 2014:195)

\section{Data 10}

Akihito: ほい! !

(Hoi!!)

Oi

Kiyotaka: はい、何でしょう?

(Hai, nan deshou?)

Ya, ada masalah?

Akihito: なんか俺だけあつづかいざつじやね?

(Nanka ore dake atsudzukai zatsu ja ne?)

Entah kenapa kamu hanya bersikap kasar padaku saja, ya?

Kiyotaka: おおやー。これはいいなこと。ご自分から突っかかってこられたのに。面白い方です ね。

(ooya-, kore wa ii na koto. Go-jibun kara tsukakatte korareta no ni. Omoshiroi kata desu ne.) Astaga. Ini reaksi yang aneh. Padahal kamu menghinaku lebih dulu. Kamu orang yang menarik ya.

Situasi:

Kiyotaka diundang oleh keluarga Kajiwara untuk mengungkap kasus terbakarnya warisan lukisan dari kepala rumah tangga di keluarga Kajiwara. Kiyotaka dan Aoi disambut dengan baik oleh istri Kajiwara dan kedua anaknya. Namun hanya satu anak yang tidak menyambut Kiyotaka dengan baik yakni Akihito. Sehingga ketika Akihito diwawancara mengenai masalah keluarganya, Kiyotaka membalas perbuatan Akihito dengan selalu cepat-cepat memotong penjelasan Akihito. Akihito memprotes perbuatan Kiyotaka tetapi Kiyotaka mengingatkan kembali apa yang telah diperbuat oleh Akihito dengan menyindir. Lalu Akihito pun terdiam.

Analisis:

Data 10 merupakan tuturan Kiyotaka kepada Akihito. Kiyotaka menggunakan salah satu jenis bikago yakni go-kango. Bentuk dari go-kango adalah go-jibun yang memiliki arti diri sendiri.

Berdasarkan situasi tuturan Akihito meremehkan dan bersikap tidak sopan kepada Kiyotaka yang di undang kerumah Kajiwara untuk memecahkan kasus keluarga Kajiwara. Pelakuan Akihito tersebut dibalas oleh Kiyotaka dan menyindir perilaku Akihito. Penggunaan bikago bertujuan untuk membalas perbuatan Akihito yang berperilaku tidak sopan kepada Kiyotaka terlebih dahulu. Berdasarkan hal tersebut terdapat fungsi bikago yang digunakan oleh Kiyotaka yakni menyatakan sindiran kepada Akihito. Kiyotaka membalas dendam atas perbuatan tidak sopan Akihito kepada Kiyotaka. Hal ini sesuai dengan teori Hinata (dalam Sudjianto dan Dahidi. 2014:195) bikago dapat berfungsi untuk menyatakan sindiran.

\section{Simpulan dan Saran}

Berdasarkan hasil yang telah dianalisis dapat disimpulkan bahwa bentuk penggunaan bikago dalam anime Kyoto Teramachi Sanjou no Holmes ditemukan o-wago, go-kango, dan o- 
JPBJ, Vol. 7 No. 1, Februari 2021

ISSN: 2613-9618

kango. Jumlah data yang ditemukan sebanyak 18 data. bentuk o-wago ditemukan sebanyak 10 data. Bentuk go-kango ditemukan sebanyak 2 data. Sedangkan bentuk o-kango ditemukan sebanyak 6 data. fungsi bikago yang ditemukan dalam anime Kyoto Teramachi Sanjou no Holmes yakni untuk menyatakan penghormatan, menjaga jarak, menyatakan kasih sayang, menyatakan jarak, menyatakan sindiran atau celaan, dan menyatakan formal.

Fungsi bikago yang cenderung digunakan adalah menjaga martabat. Hal ini sejalan dengan teori Ide dan Yoshida (dalam Tsujimura. 2002) bahwa bikago untuk menyatakan menjaga martabat penutur dengan memberikan kesan baik dan sopan kepada mitra tutur. Sedangkan fungsi bikago untuk menyatakan jarak jarang digunakan dan hanya digunakan ketika pada awal episode ketika Aoi dan Kiyotaka bertemu di toko Kura.

Sehingga dapat disimpulkan bahwa penggunaan bikago dalam anime Kyoto Teramachi Sanjou no Holmes bisa digunakan oleh lelaki dan perempuan bergantung pada pengetahun dan profesi yang dimiliki oleh penutur. Seperti dalam anime Kyoto Teramachi Sanjou no Holmes penggunaan bikago lebih sering digunakan laki-laki karena tokoh utama laki-laki merupakan penilai barang antik yang memiliki pengetahuan lebih tinggi daripada pemeran wanita. Sedangkan Aoi lebih sedikit menggunakan bikago. Hal ini dikarenakan profesi dan didikan keluarga biasa yang berbeda.

Adapun beberapa kekurangan selama penelitian dilakukan sehingga dapat digunakan saran untuk penelitian berikutnya yakni untuk dapat mengkaji penggunaan jenis bikago berupa gowago yang tidak ditemukan dalam penelitian ini. Selain itu, untuk penelitian selanjutnya, dalam meneliti data tentang bikago hendaknya untuk lebih memperhatikan dalam memilah data karena kecenderungan data bikago (memperindah kata) serupa dengan sonkeigo (meninggikan lawan tutur) dan kenjougo (merendahkan diri sendiri atau penutur).

\section{Daftar pustaka}

Adnyani. Kadek Eva Krisna. 2017. "Do Japanese Mothers Talk Differently to Daughters Than Sons? A Study of Bikago (Beautified Speech). Makalah disajikan dalam The $2^{\text {nd }}$ International Conference on Innovative Research Across Disciplines (ICIRAD 2017). Institute for Research and Community Services, Universitas Pendidikan Ganesha. Bali, 26 Agustus 2017.

Hori, Yoshio. 2010. O to Go no Tougeki Tokuchou. Kitami Kougyou Daigaku Ronbunshuu. Volume 1.

Lutvita, Alfi Alazzahrowani Ayu. 2013. Penggunaan Bikago 「美化語」dalam Drama. Skripsi tidak diterbitkan. Fakultas Bahasa dan Seni. Universitas Negeri Surabaya.

Sudjianto dan Ahmad Dahidi. 2014. Pengantar Linguistik Bahasa Jepang. Jakarta Pusat: Kesaint Blanc.

Surastina. 2011. Pengantar Semantik \& Pragamatik. Yogyakarta: New Elmatera.

Takahashi Keiko. 2016. Shizen na Keigo ga Kihon Kara Miraku Hon. Kenkyuusha.

Tsujimura Natsuko (Ed). 2002. "The Handbook Japanese of Linguistics". Wiley-Blackwell. 